\title{
FIRST RECORD OF BEAUVERIA BASSIANA (HYPHOMYCETES: MONILIALES) ON ADULTS OF CASSAVA LACE BUG VATIGA MANIHOTAE (DRAKE) (HEMIPTERA: TINGIDAE) IN BRAZIL
}

\author{
L.F.A Alves ${ }^{1}$, P.P. Bellon ${ }^{1}$, A.R. Rheinheimer ${ }^{2}$, V. Pietrowski ${ }^{2}$ \\ ${ }^{1}$ Universidade Estadual do Oeste do Paraná, Centro de Ciências Biológicas e da Saúde, Laboratório de Biotec- \\ nologia Agrícola, Rua Universitária, 2069, CEP 85819-110, Cascavel, PR, Brasil. E-mail: lfaalves@unioeste.br
}

\begin{abstract}
Adults of Vatiga manihotae (Drake) were collected on cassava plantation (Manihotae esculenta Crantz), fécula branca variety, in Marechal Cândido Rondon, West region of Paraná state, Brazil, showing symptoms of fungi infection. Isolation and fungi identification procedures were performed. After that, Koch's postulates were used to prove the link between the fungus and insect and i noculated insects showed symptoms similar to the previously observed. Fungus was identified as Beauveria bassiana and caused the death of $14 \%$ of the insects 10 days after inoculation. This is the first record of natural occurrence of this species of fungus infecting $V$. manihote and further studies should be conducted to evaluated new isolates to control of this species.
\end{abstract}

KEY WORDS: Biological control, entomopathogenic fungus, occurrence.

\section{RESUMO}

PRIMEIRO REGISTRO DE BEAUVERIA BASSIANA (HYPHOMYCETES: MONILIALES) EM ADULTOS DO PERCEVEJO DE RENDA DA MANDIOCA VATIGA MANIHOTAE (DRAKE) (HEMIPTERA: TINGIDAE) NO BRASIL. Adultos do percevejo de renda Vatiga manihotae (Drake) foram coletados em uma plantação comercial de mandioca (Manihotae esculenta Crantz), variedade fécula branca, em Marechal Cândido Rondon, Paraná, região Oeste do estado, Brasil, com sinais da presença de fungo sobre o corpo, sendo realizados procedimentos para isolamento e identificação do fungo. Uma vez obtido, foram utilizados os postulados de Koch para estabelecer uma relação causal entre o patógeno obtido e o inseto. Nos cadáveres observou-se a repetição da sintomatologia anterior que confirmaou a relação causal da doença. O fungo foi identificado como Beauveria bassiana e causou a morte de apenas $14 \%$ dos insetos após 10 dias de inoculação. Este é o primeiro relato natural da ocorrência desta espécie de fungo infectando $V$. manihote e novos estudos de seleção de isolados devem ser realizados.

PALAVRAS-CHAVE: Controle biológico, fungo entomopatogênicos, ocorrência.

Beauveria bassiana is one of the entomopathogenic fungi most often found associated with insects, being an important agent for controlling pests such as borers of coffee, banana and sugar cane, among others (Alves, 1998).

In cassava crop, studies have shown the fungi potential for control of green mite (Mononychellus tanajoa Bondar), whiteflies (Bemisia tuberculata Bondar) and cassava lace bug (Vatiga sp. Drake) (Bellotti et al., 1999, Oliveira et al., 2001, BarReto et al., 2004, BeLLOTTI, 2008).

However, it is emphasized that for the cassava lace bug, studies were performed with the species $V$. illudens (Drake), predominantly in the northeastern region of Brazil. In this sense, in several studies conducted under controlled conditions, the fungi B. bassiana, Metarhizium anisopliae and Sporothrix insectorum were evaluated and in general, B. bassiana stood out and the latter was the less efficient (OliveIRA et al., 2001, Schmitt, 2002, Farias; Alves, 2004, JunQUEIRA et al., 2005).

$V$. manihotae recently became more frequent in western Paraná, and studies have been performed in order to know more about the pest in such conditions (MirANDA et al., 2009).

Thus, due to there be no records so far on the association between the fungus B. bassiana and the cassava lace bug of the species V. manihotae in Brazil, the purpose of this study is to report for the first time the occurrence of this association.

${ }^{2}$ Universidade Estadual do Oeste do Paraná, Centro de Ciências Agrárias, Marechal Cândido Rondon, PR, Brasil. 
Some adults of the cassava lace bug were found killed on cassava leaves in cassava plantations (fécula branca variety) in the district of Porto Mendes, Marechal Cândido Rondon, West region of Paraná state, Brazil, with signs of infection and extrusion of fungal structures on the body. Some cadavers were collected and transferred to Petri dishes moist chamber containing sterileand moistened filter paper and were kept in plastic boxes sealed with moistened polyurethanefoam (saturatehumidity) and incubated at $26 \pm 2{ }^{\circ} \mathrm{C}$ and $14 \mathrm{~h}$ photoperiod for 7 days.

After that, fragments of these insects were also removed and transferred to the surface of glass slide, stained with Amann lactophenol with cotton blue $(0.5 \%)$, covered with coverslip and observed under light microscope $(400 \times)$ (Alves et al., 1998).

Also, other samples were taken and submitted to the process of fungi isolation described by Alves et al. (1998) in Petri dishes containing culture medium specific for this purpose ( $20 \mathrm{~g}$ oatmeal, $20 \mathrm{~g}$ agar, 550 $\mathrm{mg}$ n-dodecylgaunidine acetate, $5 \mathrm{mg}$ tetracycline, $10 \mathrm{mg}$ crystal violet). Plates were incubated for 10 days and samples of pure colonies were observed under a microscope, as previously described. Noting the presence of conidia, the fungus was inoculated on PDA culture medium (200 g potato, $20 \mathrm{~g}$ dextrose, $15 \mathrm{~g}$ agar and 1,000 $\mathrm{mL}$ distilled water) in the Petri dishes incubated for 10 days (26 $\pm 1^{\circ} \mathrm{C}$ and $14 \mathrm{~h}$ photoperiod). To confirm the species, the material obtained was referred to Dr. Richard Humber (USDA-ARS Biological Integrated Pest Management Research Unit, Robert W. Holley Center for Agriculture and Health, Tower Road, Ithaca, NY, 14853-2901).

Afterwards, a bioassay was conducted to verify the isolate pathogenicity as postulated by Koch (Alves et al., 1998). This isolate was multiplied on PDA culture medium in Petri dishes and obtained a suspension $\left(1 \times 10^{9}\right.$ conidia/mL). Thus, apical leaves of cassava plants were infested with insects wrapped with antiaphid mesh and sprayed with 1 $\mathrm{mL}$ of the fungus suspension on the lower face. After application, plants were transferred toenvironmentally controlled room $\left(25 \pm 5^{\circ} \mathrm{C}\right.$ and $12 \mathrm{~h}$ photoperiod $)$ and evaluated every 2 days for 10 days. Dead insects were collected and immersed in $70 \%$ alcohol and distilled water to surface disinfection and then transferred individually to Petri dishes moist chamber as described before. The fungus was identified as $B$. bassiana based on the characters described by HUMBER (1998), being cadavers covered by white mycelium, phialides with base globose and extending apically terminated in a zigzag (rachis), grouped into conidiophores with globose conidia, and subsequently being deposited in the bank of pathogens, Unioeste in Cascavel, PR (Unioeste 70).
In relation to its activity, it was found that the fungus caused $14 \%$ confirmed mortality differing greatly from results obtained by Oliveira et al. (2001) and JunQueIrA et al. (2005). These authors evaluated other B. bassiana isolates and observed between 80 and $100 \%$ confirmed mortality, however against another lace bug species ( $V$. illudens).

Results showed the potential of this fungus to control the pest, but further studies should be conducted with the bug $V$. manihotae in order to assess other isolates of the fungus in the control of this species.

\section{ACKNOWLEDGMENT}

We thank CNPq for supporting the first author with productivity grant, to second author with a Post Graduation (PG) grant and CAPES for the third author with PG grant.

\section{REFERENCES}

ALVES, S.B. Fungos entomopatogênicos. In: ALVES, S.B. (Ed.). Controle microbiano de insetos. Piracicaba: Fealq, 1998. chap. 11, p.289-381.

ALVES, S.B.; ALMEIDA, J.E.M.; MOINO, J.R.A.; ALVES, L.F.A. Técnicas de laboratório. In: ALVES, S.B. (Ed.). Controle microbiano de insetos. Piracicaba: Fealq, 1998. chap. 20, p.637-711.

BARRETO, R.S.; MARQUES, E.J.; GONDIM JUNIOR, M.G.C.; OLIVEIRA, J.V. Seleção de Beauveria bassiana (Bals.) Vuill. e Metarhizium anisopliae (Metsch.) Sorok. para controle do ácaro Mononychellus tanajoa (Bondar). Sciencia Agrícola, v.61, p.659-664, 2004.

BELLOTTI, A.C. Cassava Pest and their management. In: CAPINERA, J. (Ed.). Encyclopedia of entomology. New York: Springer Science, 2008. p.764-794.

BELLOTTI, A.C.; SMITH, L.; LAPOINTE, S.L. Recent advances in cassava pest management. Annual Review of Entomology, v.44, p.343-370, 1999.

FARIAS, A.R.N.; ALVES, R.T. O percevejo de renda na cultura da mandioca. Cruz das Almas: Embrapa Mandioca e Fruticultura, 2004. 2p. (Comunicado técnico, n 28).

HUMBER, R.A. Entomopathogenic fungal identification. APS/ESA workshop, 1998. Available in: <http:/ / arsef.fpsnl.cornell.edu/mycology/corner/APSwkshp. pdf> Accessed: 10 Mar. 2010.

JUNQUEIRA, N.T.V.; FIALHO, J.F.; OLIVEIRA, M.A.S.; ALVES, R.T. Patogenicidade de fungos para o percevejo de renda (Vatiga illudens) da mandioca. Revista Brasileira de Mandioca, v.18, p.59-64, 2005. 
MIRANDA, A.M.; RHEINHEIMER, A.R.; BELLON, P.P.; GAZOLA, D.; FREY-NETO, C., PIETROWSKI,

$\mathrm{V}$. Biologia do percevejo de renda (Vatiga manihotae) (Hemiptera: Tingidae) em plantas de mandioca. Revista Raízes e Amidos Tropicais, v.5, p.275-279, 2009. Available in: <http://www.cerat.unesp.br/xiiicbm/index.html> Accessed: 2 Feb. 2010.

OLIVEIRA, M.A.S.; ALVES, R.T.; FIALHO, J.F.; JUNQUEIRA, N.T.V. Patogenecidade de fungos entomógenos sobre o percevejo-de-renda da mandioca no Distrito Federal.
Planaltina: Embrapa Cerrados, 2001. 2p. (Comunicado técnico, n 45).

SCHMITT, A.T. Principais insetos da mandioca e seu controle. In: CEREDA, M.P. (Ed.). Agricultura: tuberosas amiláceas Latino Americanas. São Paulo: Fundação Cargill, 2002. p.350-369.

Received on 3/3/11

Accepted on 3/5/12 